\title{
The Food of Calanus finmarchicus during 1923.
}

\author{
By
}

\author{
Sheina Marshall, B.Sc. \\ Marine Station, Millport.
}

With 1 Figure.

IN view of the importance of Calanus as a food for fish, and especially for the Herring, its food and feeding habits have been kept under examination throughout the course of the year.

Calanus finmarchicus occurs in the Clyde sea area all the year round, and has its maximum in May and June, when it occurs in large quantities. It is scarcest during the late summer and early autumn, and is more abundant in January and February than in March and April.

The results are based on the examination of over 3000 Calanus, of which 52 per cent contained recognisable food. The number examined monthly varied, being usually greater in the months when they were abundant. The figures are shown in Table I.

\begin{tabular}{|c|c|c|c|c|c|c|c|c|c|c|}
\hline 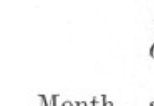 & $\begin{array}{l}\text { No. of } \\
\text { Calanus } \\
\text { ex- }\end{array}$ & & $\begin{array}{l}\text { Guts } \\
\text { contain } \\
\text { no }\end{array}$ & $\begin{array}{l}\text { Guts } \\
\text { contain } \\
\text { recog- }\end{array}$ & & Guts in & Column & five cont & taining & \\
\hline 1923 & & $\begin{array}{c}\text { empty. } \\
\%\end{array}$ & $\begin{array}{c}\text { nizable } \\
\text { re- } \\
\text { mains. } \\
\%\end{array}$ & food. & $\begin{array}{c}\text { Di- } \\
\text { atoms. } \\
\%\end{array}$ & $\begin{array}{c}\text { Dino- } \\
\text { flagel- } \\
\text { lates. } \\
\%\end{array}$ & $\begin{array}{c}\text { Silico- } \\
\text { flagel- } \\
\text { lates. } \\
\%\end{array}$ & $\begin{array}{c}\text { Cocco- } \\
\text { litho- } \\
\text { phores. } \\
\text { \% }\end{array}$ & $\begin{array}{l}\text { Radio- } \\
\text { larians. } \\
\%\end{array}$ & $\begin{array}{c}\text { Crusta- } \\
\text { ceans. } \\
\%\end{array}$ \\
\hline January. & 179 & 38 & 43 & 19 & 38 & 0 & 6 & 0 & 54 & 27 \\
\hline February. & 328 & 24 & 30 & 46 & 36 & 0 & 1 & 0 & 58 & 48 \\
\hline March. & 135 & 27 & 15 & 58 & 57 & 1 & 3 & 0 & 43 & 39 \\
\hline April. & 268 & 28 & 7 & 65 & 99 & 4 & 0 & 4 & 1 & 7 \\
\hline May. & 256 & 27 & 7 & 66 & 96 & 7 & 0 & 1 & 1 & 9 \\
\hline June. & 241 & 28 & 9 & 63 & 95 & 5 & 0 & 12 & 0 & 25 \\
\hline July. & 141 & 21 & 13 & 66 & 80 & 43 & 1 & 17 & 0 & 28 \\
\hline August. & 120 & 22 & 16 & 62 & 68 & 42 & 8 & 3 & 0 & 22 \\
\hline September. & . 130 & 21 & 10 & 69 & 91 & 21 & 30 & 0 & 0 & 13 \\
\hline October. & 155 & 28 & 2 & 70 & 100 & 3 & 7 & 0 & 0 & 12 \\
\hline November. & 257 & 31 & 19 & 50 & 91 & 5 & 6 & 0 & 17 & 16 \\
\hline $\begin{array}{c}\text { December. } \\
1924\end{array}$ & 336 & 41 & 29 & 30 & 73 & 3 & 6 & 0 & 35 & 16 \\
\hline January. & 188 & 31 & 36 & 33 & 67 & 2 & 10 & 0 & 33 & 13 \\
\hline
\end{tabular}

TABLE I.-The last six columns show the percentage number of feeding Calanus (those in column five) whose guts contain specimens of the various groups. 
The guts were, as a rule, examined fresh, for it was found much easier to identify the remains when fresh than when preserved. In cases where this could not be done the Calanus were preserved in weak formalin. It was found that after leaving them alive in the jar for several hours, all the guts were filled with copepod remains, and so the Calanus were all either preserved or examined within an hour or two of capture. Most of the food was in the form of fæcal pellets at the hind end

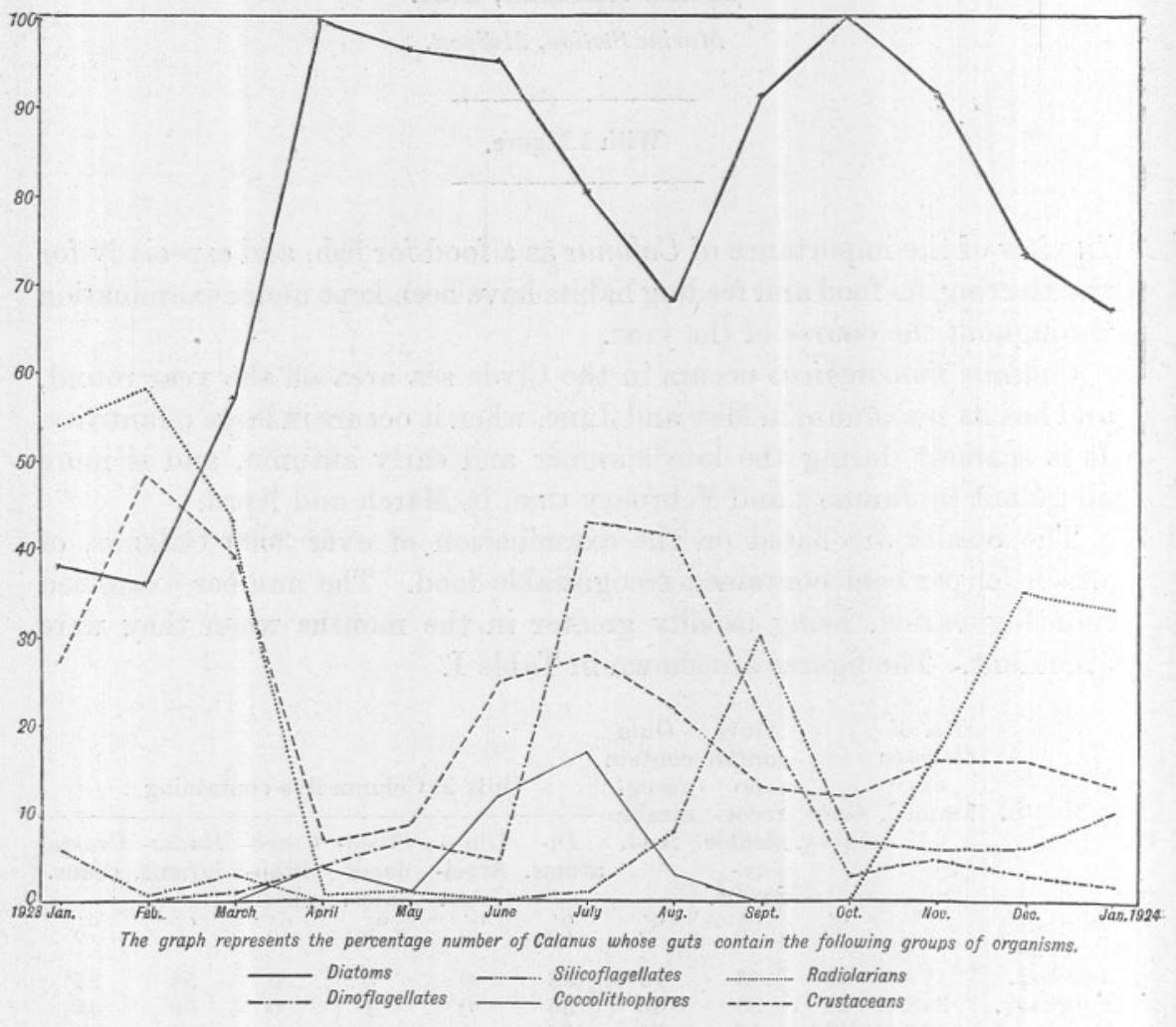

Fig. 1.

of the gut, and it is most probable that this had been taken in before capture.

The method adopted was to cut off the head of the Calanus about the level of the mouth, so as to free the front end of the gut, and then to draw out the latter with its contained food pellets, from the hinder end. The guts were then removed to a drop of clean sea water, the food pellets teased up, and examined with an oil-immersion.

A certain proportion of the guts, generally 20 to 30 per cent, was 
always empty, and a certain proportion always contained small quantities of unrecognisable brownish or greenish debris. The latter proportion varied very much, from between 30 to 40 per cent in winter to 2 per cent during the autumnal diatom maximum in October. The surprisingly small proportion of Calanus feeding in winter was later found to be due to the habits of the copepod. In winter they cease almost entirely to feed during the day and feed instead at night. From November onwards few of the Calanus contain any recognisable food until an hour or two after dark, and they stop feeding again whenever it becomes light. Even bright moonlight seems to have a deterrent effect. As spring comes on and the diatoms increase in number the proportion feeding by day grows larger, and in summer, records from the day and night differ little, although the percentage feeding is always higher in summer than in winter, even at night. The reason for this change of habit is not apparent. There are, as a rule, larger numbers of copepods, and crustacea generally, present at the surface during the day than during the night, and this holds good for summer as well as winter. The surface is probably richer in their food than the lower layers, but this does not explain the difference between summer and winter, nor the fact that moonlight seems to act in the same way as daylight.

The food consists mainly of diatoms, which confirms the previous work on the subject (Dakin, 1901; Esterly, 1916; Lebour, 1922). When diatoms are scarce other organisms are eaten instead. During the winter minimum a species of Radiolarian, Acanthonia mülleri, is common in the plankton, and this forms an important part of the diet, along with the winter diatoms, Coscinodiscus and Biddulphia. The winter 1923-4 was not so good for Radiolarians as the previous winter, and the proportion eaten was smaller.

As spring comes on, diatoms bulk more and more largely, and during the spring maximum in April almost every gut contains numbers of Skeletonema with Thalassiosira a close second. These two diatoms changed places in May, and in this month and in June Thalassiosira was eaten oftener than Skeletonema, this change corresponding with conditions in the tow-nets. Various species of Naviculids were common in April, May and June, and Fragilaria in long bands was common in the guts in the end of May and in June.

In July diatoms were still the most important food, but the species eaten this month was Rhizosolenia fragillima, a small form very abundant in the tow-nets for about three weeks. In August Rhizosolenia was still important, but (again corresponding with changes in the plankton) the species this month was $R$. shrubsolei, and Chatoceros was eaten more freely than Rhizosolenia.

A group which is of importance during the summer months is the 
Peridiniales. Gymnodinians are probably eaten much more than the records show, since they will disintegrate very rapidly. The exploded nematocysts of Polykrikos were found in one gut in September, and in July and August a small yellowish Peridinian was common. Peridinium itself was most abundant in August and September, the species most commonly eaten being $P$. pellucidum, although it was often impossible to identify the species. $P$. depressum was the species commonest in the tow-nets, and had its maximum at the end of July and beginning of August. Considering the abundance of Ceratium in August one would have expected it to be used as much as Peridinium, but such is not the case. I did not find it in any gut, nor has it been recorded by other workers. C. tripos is recorded from the gut of Centropages typicus (Lebour, 1922). Dinophysis and Phalacroma also occurred occasionally. Prorocentrum was found by Esterly to be common, but was rare here.

In the latter half of September and the beginning of October occurred the autumnal maximum of diatoms, consisting like the spring maximum of Skeletonema and Thalassiosira and the Calanus guts were again full of these diatoms. The numbers eaten decreased after this, although Thalassiosira remained of importance throughout the winter. Coscinodiscus and Biddulphia appeared in the guts in November, as did Acanthonia.

The. Silicoflagellates are eaten in small quantities, most frequently during the Distephanus maximum in September. Dictyocha is rare, and was found only once or twice, but Distephanus is occasional throughout the winter, and Ebria throughout the summer.

Pontosphara huxleyi was eaten during the summer (April to August), but although it occurred in 17 per cent of the guts in July it was never present in large numbers, and cannot be looked on as an important constituent of the food. The same may be said of the Silicoflagellates. Esterly, however, found some guts of Calanus packed with coccoliths, probably those of Pontosphara huxleyi.

A certain proportion of the Calanus are always to be found eating Crustacea. These are not often recognisable, sometimes only bristles or hairs being present, but other copepods were occasionally identified. Most were eaten in winter, and at their summer maximum.

Remains of other organisms, such as molluscan larvæ, cœlenterate nematocysts (possibly ingested on other Crustaceans), Tintinnoids (Tintinnopsis ventricosa and Tintinnus subulatus), bits of algæ and so on are occasionally found, but are of little importance.

In addition to the recognisable fragments, usually the indigestible chitinous or siliceous tests, there is always a mass of greenish or brownish debris. Part of this must be due to the contents of the diatoms or other 
food, but part is possibly due to soft-bodied organisms which leave no recognisable remains.

The food in any one gut is generally mixed. Some individual records are given below to illustrate this :-

January. (1) Masses of Coscinodiscus, some Biddulphia sinensis, many Radiolarian spines and bits of copepod.

(2) Five Acanthometrid centres and spines, and copepod remains.

April. (3) Much Skeletonema, some Thalassiosira and a bit of Coscinodiscus.

(4) Much Skeletonema, a Navicula, a bit of Biddulphia and several Ditylium brightwelli.

June. (5) Several Naviculids, a Synedra, a Peridinium pellucidum and several Pontosphara huxleyi.

July. (6) About fifty cells of Rhizosolenia fragillima.

(7) Masses of $R$. fragillima, a little Chatoceros, several Navicula and bits of other diatoms, a Tintinnus case, a Pontosphora huxleyi, numerous Gymnodinians and crustacean remains.

August. (8) Masses of Chotoceros and a Distephanus.

(9) Remains of at least nine Peridinium (mostly $P$. depressum) and two Gymnodinium.

September. (10) Bits of Chatoceros, Skeletonema, Coscinodiscus, Rhizosolenia, Naviculids, a Tintinnus subulatus, a Peridinium, and eight nematocysts of Polykrikos.

(11) A little Skeletonema, a good deal of Thalassiosira, a Distephanus and an Ebria.

November. (12) Enormous quantities of Thalassiosira, bits of Coscinodiscus, a large Naviculid and a Dinophysis.

December. (13) An Acanthonia, some Coscinodiscus and Biddulphia.

The last two records were from night tow-nettings.

Table I shows the number of copepods examined, and the number feeding. The other columns show the percentage of feeding Calanus whose guts contained specimens of the various groups of organisms. Fig. 1 expresses the same results graphically. It will be seen that the 
highest point on each curve corresponds to the time when the group was at its maximum.

The contents of the gut of Calanus are thus seen to reflect fairly accurately the progressive changes in the microplankton. Diatoms are undoubtedly the most important constituent, at least of those recognisable. In view of Pütter's calculations, estimating that to satisfy its food requirements a Calanus would need to take in daily an amount corresponding to 15,800 Coscinodiscus, or 9,750,000 Thalassiosira nana, it has sometimes been supposed that the greater part of the energy was derived from naked flagellates, ciliates, etc., which were quickly absorbed, leaving no trace. My material was examined fresh, and although there were, especially in summer, a certain number of flagellates recognisable, yet the number was not so great as to suggest that they formed the most important part of the food supply. It is not known how long the process of digestion takes in copepods, but the numbers of diatoms counted in any one gut are very far below Puitter's figures. It is difficult to estimate the number exactly, but in the case of Rhizosolenia fragillima the number is often over sixty, and in the case of Skeletonema it is very much higher. The larger diatoms, Coscinodiscus, Biddulphia and larger species of Rhizosolenia are always broken, but the number is much lower.

No particular preference is shown for any one type of diatom. The small round forms, Skeletonema, Thalassiosira and small Coscinodiscus, are certainly by far the most abundant, but this is probably due to their abundance in the plankton. Organisms with long spines (e.g. Chatoceros, Acanthonia), such as might have been supposed to afford them some protection, are eaten quite freely. When an Acanthonia is found in the gut the spines are usually broken off short, and the solid central portion remains compact, with the broken bases sticking out round it.

A few observations were made on some of the other copepods, Pseudocalanus elongatus, Temora longicornis, Acartia clausi, Centropages hamatus and Anomalocera patersoni. Conditions here were much the same as in Calanus. Diatoms formed the chief part of the food in most cases, although Temora, Centropages and Anomalocera, as Lebour found at Plymouth, are crustacean feeders to a greater extent than the others. Temora appears to be the most voracious. Its gut is practically always full and it eats a large variety of organisms.

Undoubtedly the most important diatom in the Clyde sea area, as regards food, is Skeletonema costatum. In spring, and again in autumn, it occurred in enormous quantities, and every crustacean gut examined, from Mysids and Euphausids to copepods, contained it, often in large numbers. It was also eaten by planktonic larvæ, Polychætes, Mitraria, Cyphonautes, by Appendicularians (Fritillaria furca and Oikopleura dioica) and by Ciliates and Gymnodinians. 


\section{LITERATURE.}

1908. Dakin, W. J. Notes on the Alimentary Canal and Food of the Copepods. Internat. Rev. Hydrobiologie und Hydrographie, I, p. 772 .

1916. Esterly, C. O. The Feeding Habits of Pelagic Copepods. University of California Publications in Zoology, XVI, p. 171.

1922. Lebour, M. V. The Food of Plankton Organisms. Journal of the Marine Biol. Assoc., XII, No. 4, p. 644. 